\title{
Do competition and efficiency lead to bank stability? Evidence from Bangladesh
}

\author{
Kumar Debasis Dutta ${ }^{1,2}$ and Mallika Saha ${ }^{1,3^{*}}$ (])
}

\begin{abstract}
Financial deregulation after financial repression during 1980s and 1990s has stimulated a fierce competition among banks across the world. In pace with this, banking industry of Bangladesh is also experiencing an intense competition, since it is composed of a large number of banks. Considering this upsurge, our study aims to explore the impact of competition and efficiency on financial stability of Bangladeshi banks over 2009-2017. For exploring this nexus, we calculate Boone indicator and Z-score, construct banking efficiency index by principal component analysis, using bank-level data to measure competition, stability and efficiency, respectively, and analyze the impact of efficiency on financial stability at different levels of competition. We address the endogeneity of the estimation by employing twostep system GMM and different robustness checks. The findings of our study suggest a nonlinear competition-stability relationship, and though efficiency contributes to stability, the impact is moderated in the presence of competition. Our findings are robust to alternative measures of competition, stability and control variables, which could be useful for policy makers to formulate strategies and policies to maintain financial stability.
\end{abstract}

Keywords: Boone indicator, Competition, Efficiency index, Financial stability, PCA, Two-step system GMM

\section{Introduction}

The liberalization of the financial system and reforms of banking industries across the borders have altered the functional and competitive environment for banks. Moreover, the deregulation, new market entries, metamorphosis of financial technologies, and other significant regulatory changes are imposing great challenges to maintain financial stability in this fiercely competitive market. In line with these international phenomena, the flourishing banking industry of Bangladesh is also experiencing an escalating new entry and supporting the spectacular growth of the economy and thus, demands to scrutinize the financial stability in terms of this intensifying competition and efficiency of Bangladeshi banks.

Moreover, banks in the fast-growing and emerging economies like Bangladesh exist at the top of the financial system with an immense importance. Because of having a

\footnotetext{
*Correspondence: msaha@stu.zuel.edu.cn

1 Zhongnan University of Economic and Law, Wuhan 430073, People's

Republic of China

Full list of author information is available at the end of the article
}

less developed capital market, Bangladesh mostly relies on banks to finance its economic growth and development. Higher demands for banks in developing and transitional economies as well as political consideration for licensing new banks may develop intense competition in the banking industry, and competition among banks may either result in fragility or stability of the banking system.

The literature on bank competition and financial stability to date is debated. The empirical investigations show that intense competition may either entice banks to take excessive risks and cause financial debris [4, 19], or may bring efficiency through reducing costs and price of the financial service and motivate banks to maintain a buffer capital that ensures financial stability $[41,46,48]$. Moreover, some research findings exemplify the inconclusive relation of competition with stability $[4,13,45]$.

On the other hand, there are few researches on the impact of efficiency on stability [31, 40] and impact of competition on efficiency [12, 34, 42]. Though several researchers mentioned the critical role of efficiency in competition and stability nexus, adequate initiative to 
explore the impact of efficiency on competition-stability nexus has been ignored.

Therefore, the inconclusive and widely debated relation of competition with stability $[4,13,45]$ and the dearth of research on efficiency-stability relation badly demand for such study. In addition, existing similar studies, which mainly focused on the European and Latin American banks $[31,46]$, have given a vast scope to explore the emerging and developing economies further. Therefore, our present study tries to fill all these gaps by answering two research questions focused on the banking industry of Bangladesh. Does bank competition enhance or weaken financial stability? How does efficiency influence the competition-stability relationship?

To answer these research questions, we use bank-level data of a comprehensive sample of 30 banks over 20092017 that constitute a balanced panel of 270 observations and sourced the necessary variables from the financial statements of selected banks and World Bank database. We use $Z$-score and Boone indicator to measure bank stability and competition, respectively, and construct an efficiency index by applying principal component analysis (hereafter, PCA) to measure bank efficiency. To identify the impact of competition on stability at different levels of efficiency, we include different interaction terms of competition and various efficiency measures. To deal with the possible endogeneity, we employ two-step system GMM and use alternative measures of outcome, explanatory and control variables to check the robustness of the estimation. Results of our study indicate a nonlinear relationship between competition and financial stability, and though efficiency promotes stability, the impact is moderated in the presence of competition.

Our findings contribute to the existing studies through introducing an index for baking efficiency by applying PCA and explore its impact on bank competition-stability relationship. We show that there exists nonlinearity in competition-stability nexus. Besides, though efficiency fosters stability, which becomes moderated in the presence of competition, these findings possess great policy implications, which suggest that though competition might initially contribute to stability, the positive impact diminishes and turns negative at a higher competition. Besides, it is not optimal to only focus on the efficiency prevailing in the market because without considering the level of banking competition, policies to ensure financial stability can be weak and less effective. To our knowledge, this study is the first to consider both the competition and efficiency to analyze financial stability of a developing economy's banking industry like Bangladesh.

The remainder of this paper is organized as follows: "Literature review" section discusses the review of relevant studies; "Background of banking sector of
Bangladesh" section discusses the background of banking sector of Bangladesh, "Methods" section explains the data and methodology, "Results and discussion" section presents the results and discussions and "Conclusion" section concludes.

\section{Literature review}

With a paradigm shift toward financial deregulation stemming from financial repression during 1980s and 1990s, the banking sectors, initially in developed countries and later on in developing countries, have been experiencing an accelerating level of competition that produces two opposing views related to financial stability.

Competition-stability view argues that competition has a potentially positive effect on the stability of financial institutions [46]. Arguing the same, Boyd and Nicolo [18] proposed that lower lending rates in a competitive market reduce the cost of borrowing and increase the entrepreneurial success that contributes to bank stability by reducing exposure to credit risk; in contrast, a small number of large banks in a concentrated or less competitive market can charge higher interest rates, which may increase the volume of nonperforming loan, thereby causing banking failure. Schaeck and Cihák [47] analyzed 3600 European banks and more than 8900 US banks and found competition, measured by Boone indicator as favorable for banking soundness. Schaeck et al. [48] explained that in a competitive environment banks are found to maintain a buffer capital that decreases the propensity of financial crisis; similarly, Kasman and Carvallo [31] also argued competition as favorable for financial stability. A recent paper of Noman et al. [38] analyzes the role of bank regulation on the relationship between competition and financial stability and found that both competition and regulatory policies promote financial stability and reduce credit risk in the banking system.

The competition-fragility view, on the other hand, implies that a higher competition in the financial services industry impairs the market power and profitability of the financial institutions. In order to recover from financial losses, financial institutions are more likely to invest in riskier portfolios. Consequently, this risk-taking behavior will undermine the stability of financial institutions [3, 33].

Moreover, Llewellyn [35] held excessive competition accountable for the failure of financial sectors of USA and UK. According to Allen and Gale [3, 4], in a competitive market banks have a motivation to reduce the effort of customer screening for selling more credits and earning higher profit, which may also raise the credit default risk and bank fragility. Beck et al. [10] found a positive relationship between competition and bank fragility in an economy that has a developed and regulated financial 
structure, whereas Anginer et al. [7] show that banking systems are more fragile in countries with weak supervision and private monitoring, greater government ownership of banks, and with public policies that restrict competition. In addition, they also show that variation of regulation changes the intensity of this relation. Danisman and Demirel $[22,23]$ emphasized the importance of regulations and lessen a competitive environment for bank stability. Similarly, Kasman and Kasman [32] used a Boone indicator to measure competition and concluded in favor of competition-fragility view while analyzing Turkish banking industry.

Additionally, although Boyd and Nicolo [18] proposed for the competition-stability view, however, the extension of their model by Martinez-Miera and Repullo [36] showed that the lower revenue caused by lower interest rate resulting from higher competition can make banks riskier and produce a U-shaped competition-stability relationship. Moreover, Berger et al. [13] in their research also found support for both stability and fragility views, which makes this relationship further ambiguous and research worthy.

Besides, efficiency is another factor that should be discussed with importance to explain financial stability because of its close interaction with both competition and financial stability. Allen and Gale [4] argued that competition could be favorable for efficiency and critical for financial stability. Academic discussion regarding this nexus is still underresearched and inconclusive. One strand of studies argues that competition and efficiency can be either positively $[4,12]$ or negatively 42$]$ related. Another strand indicates that the increase in efficiency helps to decline nonperforming loan [11] and has positive impact on stability [40]. Moreover, efficient banks tend to have more market power than others [31] and expected to possess lower level of risk [25], which may lead to a stable financial system.

On the other hand, Tan and Floros [49] found a positive relationship between efficiency and financial vulnerability caused by inadequate credit screening, which produces large volume of loans with minimum effort of checking and monitoring along with increasing (technical) efficiency and higher credit risk.

In addition, Altunbas et al. [5] argued that by imposing higher capital requirements regulators restrict inefficient banks from taking excessive risk and maintain stability in the industry. Therefore, these empirical evidences imply that efficiency and instability can coexist and inefficiency can exert a positive impact on financial stability. Corbae and Ross [21] show that intensification of competition increases market measures of efficiency as well as banking fragility, and economies can avoid the fragility costs of competition by enhancing bank governance and tightening leverage requirements. Alber [2] using data of 12 MENA countries investigated the relationship between banking efficiency and financial stability and found a bidirectional relationship between them.

Previous studies to this end studied and reported the impact of either competition or efficiency on stability separately. Besides, the very few researchers, who have recently studied the nexus between competition, efficiency and stability, produced mixed results. These studies found both competition and fragility views [40] with a positive impact of efficiency on stability for four East Asian economies and competition-stability view $[31,46]$ with efficiency as a conduit of stability for European, Latin American banks.

Therefore, for having inconclusive results and a vast scope of exploring the nexus between competition, efficiency and financial stability, this paper tries to explain the role of efficiency in competition-stability relationship for banks of Bangladesh over 2009-2017.

\section{Background of banking sector of Bangladesh}

Bangladesh, an emerging country, has a bank-dominant financial sector. The banking sector of Bangladesh is consisting of 57 banks, among which there are 6 stateowned commercial banks, 2 development financial institutions, 40 private commercial banks and 9 foreign commercial banks with 9955 branches across the country [8]. Despite the fact that banking sector of Bangladesh in terms of the market scale is already saturated and financial health of many banks is deteriorating, nevertheless, the numbers of banks and bank branches are increasing over the years (Fig. 1), since the license for banks to enter the industry has been issued on political considerations $[9,29,50]$. And the banking sector has therefore been experiencing an accelerated degree of competition. While Bangladesh Bank has adopted a range of policy measures, including monitoring major creditors, preventing fraud forgeries and improving internal control and compliance through self-evaluation of anti-fraud internal controls, to ensure a sound and stable performance of the banks [8], the ratio of gross NPLs to total loans remains very high. The rising trend of NPLs is a looming threat to the banking sector in Bangladesh that may stem from the increasing degree of competition, as fierce competition often lowers profitability and induces banks to compromise the standard of lending that leads to a rise in credit risk and inefficiency and eventually affects financial stability. Therefore, it is worth investigating the nexus between competition, efficiency and stability from Bangladesh's perspective. 


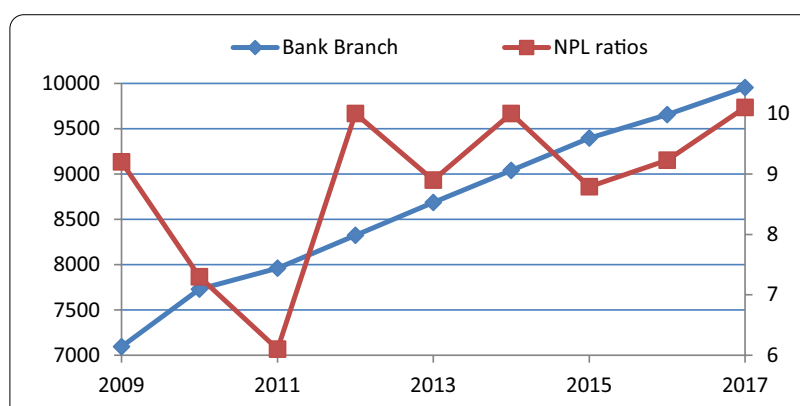

Fig. 1 Trend of bank branch and NPL ratio

\section{Methods \\ Data}

To analyze whether bank competition and efficiency influence bank stability, bank-level data of competition, efficiency, financial stability and bank-level control variables—bank size and liquidity - are sourced from financial statements of concerned banks which are available at their websites and Dhaka Stock Exchange library. In addition, data of country-level control variables-governance-are collected from The Worldwide Governance Indicators dataset [53], regulation is collected from Economic Freedom Index [26], and others are collected from World Development Indicator [54] for the period 2009-2017, which constitute a balance panel of 270 observations. Data sources and variable definitions are presented in "Appendix" Table 6. Prior to the analysis, all data are winsorized at 1st and 99th percentile to reduce the influence of outliers.

\section{Financial stability}

To measure financial stability, a wide range of indicators were devised following the global financial crises of 1980 s and 1990s, like $Z$-score, probability of bankruptcy, standard deviation of ROA, nonperforming loan ratio and so on, among which $Z$-score is very common and used by many researchers $[6,10,27,32,37]$. $Z$-score measures the insolvency risk of a bank; a larger value indicates a lesser risk of bankruptcy and a higher bank stability. We use natural logarithm of the $Z$-score to measure bank financial stability that accounts for skewness in the data. $Z$-score is computed as follows:

$$
Z \text {-score } i t=\frac{\mathrm{ROA}_{\mathrm{it}}+\left(\frac{E}{\mathrm{TA}}\right)_{\mathrm{it}}}{\sigma \mathrm{ROA}_{\mathrm{it}}}
$$

where $\mathrm{ROA}$ is the return on assets, $E / \mathrm{TA}$ represents the equity to total assets ratio, and $\sigma$ ROA denotes the standard deviation of return on assets. We use three-year rolling time windows to compute the standard deviation of ROA to allow for time variation in the denominator of the $Z$-score. In addition, standard deviation of return on asset (hereafter, $\sigma \mathrm{ROA}$ ) and nonperforming loan ratio (NPL) are also used as a measure of financial stability [1, 32] to check the robustness of the estimations.

\section{Competition}

To determine competition $\mathrm{H}$-statistic, concentration ratios, Lerner index, Boone indicator and other measures could be used. Structural measures like HHI (Herfindahl-Hirschman index) represent competition through level of concentration, which is found as a delicate proxy of competition [20] and therefore could generate misleading outcomes. Moreover, a high degree of industry concentration does not necessarily imply a less competitive market [39]. On the other hand, Lerner index is also criticized for not being able to confine the degree of product substitutability [51], whereas Boone indicator, introduced by Boone $[16,17]$, is found to overcome these shortcomings and employed by some researchers like Schaeck and Cihák [46], Saif-Alyousfi et al. [45], Kasman and Kasman [32], Saha and Dutta [44]. Following the relevance, this study also uses Boone indicator to measure the competition. Boone [17] calculates the level of competition by estimating the elasticity of a firm performance, in terms of its market shares, with respect to its marginal costs, as follows:

$$
\ln (\text { Market share })_{\mathrm{it}}=\alpha+\beta \ln (\text { Marginal cost })_{\mathrm{it}}
$$

where the coefficient $\beta$ denotes the Boone indicator. Following Schaeck and Cihák [46], we approximate the marginal costs by calculating the average variable costs as marginal costs cannot be observed directly. For the baseline GMM estimation and robustness check, we use market share of total loan (hereafter, Boone loan) and market share of total deposits (hereafter, Boone deposit), respectively, to estimate Boone indicator. In principle, Boone indicator argues that competition creates a negative relation between performance and marginal cost that becomes stronger at a higher level of competition. Higher negative value of the Boone indicator signifies higher competition; therefore, we transform Boone indicator to its respective positive value to facilitate interpretation.

\section{Efficiency}

Many researchers used data envelopment analysis (DEA) to measure efficiency; however, efficiency ratios-working capital ratio, asset turnover ratio and operating efficiency-are simple and easy to understand and can be used to measure prevailing operational efficiency in an organization [52]. In this paper, we use different efficiency ratios, namely net interest margin, working capital ratio, asset turnover ratio and operating efficiency ratio, to measure bank efficiency. Since different efficiency ratios are highly correlated, substitutable or complementary in nature, the simultaneous use of those indicators 
in a model may produce unreliable results. Therefore, to overcome this problem of over-parameterizations and multicollinearity, we use different efficiency ratios to construct efficiency index applying the PCA [28]. Before applying the PCA, all indicators are normalized using the following equation:

$$
\mathrm{nmx}=\frac{X_{i}-X_{\min }}{X_{\max }-X_{\min }}
$$

where $X_{\min }$ is the minimum data point and $X_{\max }$ is the maximum data point.

The eigenvalues of the four components are 1.56, 0.98, 0.85 and 0.59 , respectively, suggesting that the first component has eigenvalue higher than one and explains 39\% variations of the four ratios. We consider only the first component to construct the efficiency index for all our bankyear observations and again normalize the resulted index using minmax normalization. The Kaiser-Meyer-Olkin (KMO) measures of sampling adequacy are 0.56 , and the $p$ values for the Bartlett's test of sphericity are lower than the 0.01 significance level, which confirms the suitability of the variables used in the PCA. Additionally, we use operating efficiency ratio for the robustness check of the estimation.

\section{Control variables}

To control the bank-specific heterogeneity and economic condition, we use different control variables. Similar to Jeon and Lim [30], loan to deposit is used to control the liquidity and log of total asset is used to control bank size, which is also used by Kasman and Kasman [32] and Jeon and Lim [30]. Furthermore, similar to Ahamed and Mallick [1] to control the fluctuations of economic activity, log of GDP per capita and GDP growth rate (gGDP) are used. To account for the variation of governance and regulation over time, a composite index of governance, constructed similar to Dutta and Saha [24], and regulation is used. Additionally, financial depth measured by broad money to GDP and log of real GDP are used as alternative control variables for robustness check.

\section{Model}

To estimate the direct causal effect of competition and efficiency, we use the following model, where an interaction term of competition and efficiency is also included to capture the degree of change in competition-stability nexus at different levels of efficiency. where subscripts $i$ and $t$ indicate bank and time, respectively, the dependent variable Financial Stability $y_{\text {it }}$ is measured by either $\log (Z-\mathrm{Score})$ or $\sigma \mathrm{ROA}$ or NPL, the lagged value of this variable is included as regressors to capture the persistence of financial stability. Competition $_{\mathrm{it}-1}$ is the 1-year lagged term of competition for bank i measured by either Boone loan or Boone deposit. Additionally, following Berger et al. [13], we use a quadratic term of competition to capture the nonlinear properties of competition-stability relationship. Other independent variables like Efficiency ${ }_{\text {it-1 }}$ are measured by either efficiency index constructed by PCA or operating efficiency ratio. $X_{i t-1, j}$ is a set of $\{k\}$ variables controlling for bank-specific and macroeconomic factors. $\beta$ 's are the parameter vectors, $v_{t}$ are the year dummies and $\varepsilon_{i t}$ is the unobserved disturbance. We take lag of all explanatory variables to reduce the endogeneity issues. The inclusion of time dummies captures the effect of any event that affects the variables of interest for all banks and ensures that the estimates are not biased because of the occurrence of any such events. To address the possible endogeneity, we apply the two-step system GMM [14]. The system GMM estimator provides consistent and efficient estimates, overcomes the unobserved effects and endogeneity problem and is a better fit for panel studies with fewer time observations like this study. We also check the robustness of the validity of the instruments and any possible autocorrelation using the Sargan test and Hansen J statistic of over-identifying restrictions and Arellano-Bond (AR) test, respectively.

\section{Results and discussion Descriptive statistics}

Table 1 presents descriptive statistics of data used in this study. The mean value and standard deviation of $\log (Z$-score $)$ are 3.28 and 0.85 , respectively, showing an overall stable state; however, the minimum value 0.31 represents some banks are susceptible to financial distress. The minimum values of -3.965 and -4.956 , the maximum values of -3.105 and -2.496 and the mean values of -3.49 and -3.597 are associated with the Boone loan and Boone deposit, respectively, and show a high level of competition in banking industry. The standard deviation of efficiency index (0.787) and loan to deposit ratio (1.732) indicate high variations of

$$
\begin{aligned}
\text { Financial Stability }_{\mathrm{it}}= & \beta_{0}+\beta_{1} \text { Financial Stability }_{\mathrm{it}-1}+\beta_{2} \text { Competition }_{\mathrm{it}-1}+\beta_{3} \text { Competition }_{\mathrm{it}-1}^{2} \\
& +\beta_{4} \text { Efficiency }_{\mathrm{it}-1}+\beta_{5} \text { Competition }_{\mathrm{it}-1} \times \text { Efficiency }_{\mathrm{it}-1}+\sum_{j=1}^{k} \gamma_{j} X_{\mathrm{it}-1, j}+v_{t}+\varepsilon_{\mathrm{it}}
\end{aligned}
$$


Table 1 Descriptive statistics

\begin{tabular}{lcclll}
\hline Variable & Obs. & Mean & SD & Min. & Max. \\
\hline log (Z-score) & 270 & 3.279 & 0.851 & 0.31 & 5.006 \\
oROA & 240 & 0.006 & 0.009 & 0 & 0.051 \\
NPL & 270 & 0.0926 & 0.157 & 0.0008 & 0.902 \\
Boone loan & 270 & -3.49 & 0.176 & -3.965 & -3.105 \\
Boone deposit & 270 & -3.597 & 0.504 & -4.956 & -2.496 \\
Net interest margin & 270 & 0.033 & 0.014 & 0.001 & 0.076 \\
Asset turnover ratio & 270 & 0.879 & 0.715 & 0.484 & 7.765 \\
Operating efficiency ratio & 270 & 2.329 & 0.69 & 0.105 & 4.902 \\
Working capital ratio & 270 & 3.367 & 3.78 & 0.122 & 32.013 \\
Efficiency index & 270 & 0.787 & 0.0897 & 0 & 1 \\
log (total asset) & 270 & 25.672 & 0.698 & 23.19 & 27.31 \\
Loan-to-deposit ratio & 270 & 1.163 & 1.732 & 0.394 & 21.173 \\
gGDP & 270 & 6.292 & 0.669 & 5.045 & 7.284 \\
log(GDP) & 270 & 25.658 & 0.161 & 25.416 & 25.916 \\
log (GDP per capita) & 270 & 6.933 & 0.257 & 6.554 & 7.355 \\
Financial depth & 270 & 61.662 & 3.396 & 54.882 & 65.848 \\
Governance & 270 & 0.408 & 0.348 & 0 & 1 \\
Regulation & 270 & 6.797 & 0.877 & 6.63 & 6.9 \\
\hline
\end{tabular}

efficiency and liquidity across banks. All other variables show moderate variation.

\section{Baseline estimation}

Table 2 shows the results of two-step system GMM estimations. Lag of financial stability is positive and significant in all models, and the coefficients remain in between the coefficient of fixed effect (0.31) and pooled (0.52) estimation, ${ }^{1}$ which indicate the reliability of estimations as discussed by Bond [15] as follows:

.... the autoregressive coefficient is biased upwards in the pooled ordinary least square (POLS) estimation, while being biased downwards in the fixed effect (FE) estimation, thus the consistent estimates of the autoregressive coefficient should lie between the FE and the POLS estimates of the autoregressive coefficient.

We treat financial stability, competition, efficiency, bank size and liquidity as endogenous and log (GDP per capita), GDP growth rate, governance, regulation and year dummies as exogenous and use different period lag of those variables as instruments in the first-difference equations in all models. We check the validity of the instruments using the Sargan test and Hansen J statistic

\footnotetext{
${ }^{1}$ The results of the fixed effect and pooled estimation are available on request.
}

Table 2 GMM estimation, dependent variable: financial stability

\begin{tabular}{|c|c|c|c|}
\hline Variables & (1) & (2) & (3) \\
\hline Financial stability $_{t-1}$ & $0.486^{* * *}(0.036)$ & $\begin{array}{r}0.461^{* * *} \\
(0.054)\end{array}$ & $\begin{array}{r}0.491^{* * *} \\
(0.057)\end{array}$ \\
\hline Competition $_{t-1}$ & $9.504^{* * *}(3.546)$ & $\begin{array}{c}12.145^{* * *} \\
(4.679)\end{array}$ & $\begin{array}{l}26.105^{* * *} \\
(5.810)\end{array}$ \\
\hline Competition ${ }_{t-1}^{2}$ & $-9.428^{* * *}(3.366)$ & $\begin{array}{l}-12.235^{* * *} \\
(4.539)\end{array}$ & $\begin{array}{l}-23.411^{* * *} \\
(5.429)\end{array}$ \\
\hline Efficiency $_{t-1}$ & & $\begin{array}{r}4.866^{* * *} \\
(1.446)\end{array}$ & $\begin{array}{l}1.519^{*} \\
(0.896)\end{array}$ \\
\hline \multicolumn{2}{|c|}{ Competition $_{t-1} \times$ Efficiency $_{t-1}$} & & $\begin{array}{l}-3.619^{* * *} \\
(0.877)\end{array}$ \\
\hline Bank size $_{t-1}$ & $0.272^{*}(0.155)$ & $0.199(0.202)$ & $\begin{array}{r}0.569^{* *} \\
(.231)\end{array}$ \\
\hline Liquidity $_{t-1}$ & $0.001(0.053)$ & $\begin{array}{r}0.322^{* * *} \\
(0.050)\end{array}$ & $\begin{array}{c}0.497^{* * *} \\
(.043)\end{array}$ \\
\hline Log(GDP per capita) ${ }_{t-1}$ & $0.400^{* * *}(0.106)$ & $0.039(0.183)$ & $\begin{array}{r}-0.025 \\
(0.168)\end{array}$ \\
\hline $\mathrm{gGDP}_{t-1}$ & $-0.265^{* * *}(0.033)$ & $\begin{array}{l}-0.345^{* * *} \\
(0.042)\end{array}$ & $\begin{array}{l}.502^{* * *} \\
(0.061)\end{array}$ \\
\hline Governance $_{t-1}$ & $0.097(0.149)$ & $\begin{array}{r}0.661^{* * *} \\
(0.251)\end{array}$ & $\begin{array}{r}0.872^{* * *} \\
(0.248)\end{array}$ \\
\hline Regulation $_{t-1}$ & $0.223^{* * *}(0.039)$ & $0.087(0.057)$ & $005(.059)$ \\
\hline Constant & $-0.116^{*}(0.062)$ & $\begin{array}{r}3.547^{* * *} \\
(1.067)\end{array}$ & $\begin{array}{l}0.742 \\
\quad(1.463)\end{array}$ \\
\hline Year dummies & Yes & Yes & Yes \\
\hline No. of instruments & 28 & 28 & 28 \\
\hline $\operatorname{AR}(2)$ & 0.78 & 0.98 & 0.82 \\
\hline Hansen statistics & 0.17 & 0.19 & 0.48 \\
\hline Observations & 210 & 210 & 210 \\
\hline No. of banks & 30 & 30 & 30 \\
\hline
\end{tabular}

Standard errors in parentheses. ${ }^{* * *} p<0.01,{ }^{* *} p<0.05,{ }^{*} p<0.1$. Here, financial stability, competition, efficiency, bank size and liquidity are measured by log(ZScore), Boone indicator using market share of loan, PCA of net interest margin ratio, operating efficiency ratio, working capital ratio and asset turnover ratio, $\log$ (Total asset) and loan-to-deposit ratio, respectively

of over-identifying restrictions, which confirms that the over-instrumentation problem is minimized. In addition, following Roodman [43] we use collapse option to limit the number of instruments preventing the model from being over-fitted and ensure that the number of instruments used is less than the number of banks (groups) in all models. Moreover, the results of ArellanoBond test (AR2) validate that there is no second-order autocorrelation.

In model (1), we use only Boone indicator with other control variables to estimate total causal effect of competition to on financial stability and find that the level of lag term is positively significant at 1 percent and squared lag terms of competition are negatively significant at 1 percent. This finding signifies a nonlinear, bell-shaped relationship between competition and stability, and competition initially contributes to stability; however, 


\begin{tabular}{|c|c|c|c|}
\hline Variables & (1) & (2) & (3) \\
\hline Financial stability $y_{t-1}$ & $\begin{array}{r}0.486^{* * *} \\
(0.036)\end{array}$ & $\begin{array}{r}0.422^{* * *} \\
(0.057)\end{array}$ & $\begin{array}{r}0.519^{* * *} \\
(0.072)\end{array}$ \\
\hline Competition $t-1$ & $\begin{array}{c}7.261^{* *} \\
(2.903)\end{array}$ & $\begin{array}{c}11.821^{* * *} \\
(4.401)\end{array}$ & $\begin{array}{r}11.310^{* *} \\
(5.663)\end{array}$ \\
\hline Competition ${ }_{t-1}^{2}$ & $\begin{array}{c}-0.953^{* * *} \\
(0.340)\end{array}$ & $\begin{array}{l}-1.509^{* * *} \\
(0.537)\end{array}$ & $\begin{array}{c}-1.364^{* *} \\
(0.679)\end{array}$ \\
\hline Efficiency $_{t-1}$ & & $\begin{array}{r}3.571^{* * *} \\
(1.228)\end{array}$ & $\begin{array}{l}8.544^{*} \\
(4.984)\end{array}$ \\
\hline Competition $_{t-1} \times$ Efficiency $_{t-1}$. & & & $\begin{array}{c}-3.129 * * \\
(1.447)\end{array}$ \\
\hline Bank size $_{t-1}$ & $\begin{array}{l}0.272^{*} \\
(0.155)\end{array}$ & $\begin{array}{l}0.184 \\
(0.206)\end{array}$ & $\begin{array}{l}0.262 \\
(0.208)\end{array}$ \\
\hline Liquidity $_{t-1}$ & $\begin{array}{l}0.001 \\
(0.053)\end{array}$ & $\begin{array}{l}0.079 \\
(0.079)\end{array}$ & $\begin{array}{l}195^{* * *} \\
(0.062)\end{array}$ \\
\hline Log(GDP per capita) $)_{t-1}$ & $\begin{array}{r}0.400^{* * *} \\
(0.106)\end{array}$ & $\begin{array}{l}0.129 \\
(0.176)\end{array}$ & $\begin{array}{r}-0.402 \\
(0.273)\end{array}$ \\
\hline $\mathrm{gGDP}_{t-1}$ & $\begin{array}{l}-0.265^{* * *} \\
(0.033)\end{array}$ & $\begin{array}{l}-0.300^{* * *} \\
(0.076)\end{array}$ & $\begin{array}{l}-0.429^{* * *} \\
(0.127)\end{array}$ \\
\hline Governance $_{t-1}$ & $\begin{array}{l}0.097 \\
(0.149)\end{array}$ & $\begin{array}{r}0.837^{* * *} \\
(0.264)\end{array}$ & $\begin{array}{r}1.202^{* * *} \\
(0.437)\end{array}$ \\
\hline Regulation $_{t-1}$ & $\begin{array}{r}0.223^{* * *} \\
(0.039)\end{array}$ & $\begin{array}{l}0.136 \\
(0.085)\end{array}$ & $0.032(.123)$ \\
\hline Constant & $\begin{array}{l}-13.673^{* *} \\
(5.950)\end{array}$ & $\begin{array}{l}-21.368^{* *} \\
(8.577)\end{array}$ & $\begin{array}{r}-21.881^{*} \\
(11.164)\end{array}$ \\
\hline Year dummies & Yes & Yes & Yes \\
\hline No. of instruments & 28 & 28 & 28 \\
\hline $\operatorname{AR}(2)$ & 0.78 & 0.70 & 0.99 \\
\hline Hansen statistics & 0.18 & 0.45 & 0.34 \\
\hline Observations & 210 & 210 & 210 \\
\hline No. of banks & 30 & 30 & 30 \\
\hline
\end{tabular}

Standard errors in parentheses. ${ }^{* * *} p<0.01,{ }^{* *} p<0.05,{ }^{*} p<0.1$. Here, financial stability, competition, efficiency, bank size and liquidity are measured by $\log (Z-$ Score), Boone indicator using market share of deposit, operating efficiency ratio, $\log$ (Total asset) and loan-to-deposit ratio, respectively

as competition rises, the positive impact of competition diminishes and turns negative. Therefore, our study supports both stability and fragility views.

Competition contributes to stability through efficiency channel [46] and risk-shifting effect [36] as well as by lessening information asymmetry; however, higher competition impairs the market power and profitability of the financial institutions and to recover the losses, financial institutions are more likely to invest in riskier portfolio and/or without proper screening of borrowers, which in turn hampers the stability. This result corroborates the findings of Phan et al. [40].

In model (2) to estimate the direct causal effect of competition and efficiency on financial stability, we include both competition and efficiency as regressor and find that the impact of competition is similar to model (1) and efficiency contributes to financial stability.
In model (3), an interaction term of competition and efficiency is also included to capture the degree of change in efficiency-stability relationship at different levels of competition, and the result shows impact of efficiency on stability is negatively moderated in the presence of competition. In all models, bank size is positively significant except in model (2), where it is positive but not significant, suggesting that larger bank size matters for financial stability. Liquidity and governance have significant positive association with financial stability except in model (1) where it is positive but insignificant, suggesting that liquidity and good governance foster bank stability. GDP per capita and regulation are positive in all models but only significant in model (1). Growth rate of GDP is significant and negative in all models, which imply that increased economic growth has a negative impact on stability.

\section{Robustness check: alternative measures of independent variables}

Table 3 shows the results of robustness check of the baseline models using alternative measures of competition (Boone indicator-deposit) and efficiency (operating efficiency ratio). Similar to previous result reported in Table 2, the level of lag term is positively significant and squared lag terms of competition are negatively significant signifying bell-shaped relationship between competition and stability. The coefficient of efficiency is positively significant, whereas the moderating term of competition and efficiency is negative and significant, suggesting that efficiency contributes to financial stability; however, this synergy is negatively moderated in the presence of competition. Bank size, liquidity, governance, regulation are positive, and GDP growth rate (gGDP) is negatively significant in all models. All these results are consistent with the results of our baseline models presented in Table 2.

\section{Robustness check: alternative measures of dependent variable}

Table 4 shows the results of robustness check of the baseline models using alternative measures of financial stability, $-\sigma$ ROA and NPL. Lesser $\sigma$ ROA and NPL implies stability and vice versa, which is opposite to $Z$-score. In all models, the level lag term and quadratic lag term of competition are negatively and positively significant at $1 \%$, respectively, which suggest a curvature relationship between competition and stability. Efficiency is negatively significant, and the moderating term is positive and significant. Governance and regulation are negatively significant in all models. Bank size, liquidity and log (GDP 
Table 4 Robustness check using alternative measure of financial stability

\begin{tabular}{|c|c|c|c|c|c|c|}
\hline \multirow[t]{2}{*}{ Variables } & \multicolumn{3}{|l|}{$\sigma \mathrm{ROA}$} & \multicolumn{3}{|l|}{ NPL } \\
\hline & $(1)$ & (2) & (3) & $(4)$ & (5) & (6) \\
\hline Financial stability $_{t-1}$. & $0.553^{* * *}(0.019)$ & $0.585^{* * *}(0.024)$ & $0.596^{* * *}(0.033)$ & $0.499 * * *(0.021)$ & $0.507^{* * *}(0.022)$ & $\begin{array}{r}0.483^{* * *} \\
(0.032)\end{array}$ \\
\hline Competition $_{t-1}$ & $-0.071^{* * *}(0.009)$ & $-0.066^{* * *}(0.009)$ & $-0.098^{* * *}(0.016)$ & $-10.082^{* * *}(0.635)$ & $-9.850^{* * *}(0.623)$ & $\begin{array}{c}-8.410^{* * *} \\
(0.637)\end{array}$ \\
\hline Competition $_{t-1}^{2}$ & $0.074^{* * *}(0.009)$ & $0.069^{* * *}(0.009)$ & $0.095^{* * *}(0.014)$ & $1.360^{* * *}(0.087)$ & $1.328^{* * *}(0.084)$ & $\begin{array}{r}1.222^{* * * *} \\
(0.095)\end{array}$ \\
\hline Efficiency & & $-0.006^{* *}(0.002)$ & $-0.008^{*}(0.004)$ & & $-0.169^{* * *}(0.063)$ & $\begin{array}{l}-3.213^{* * *} \\
(1.033)\end{array}$ \\
\hline Competition $_{t-1} \times$ Efficiency & & & $0.007^{* *}(0.003)$ & & & $\begin{array}{r}0.933^{* * *} \\
(0.284)\end{array}$ \\
\hline Bank size & $-0.000(0.000)$ & $-0.000(0.000)$ & $-0.001 *(0.001)$ & $-0.059^{* * *}(0.005)$ & $-0.038^{* * *}(.007)$ & $\begin{array}{c}-0.034^{* * *} \\
(0.010)\end{array}$ \\
\hline Liquidity & $-0.001^{* * *}(0.000)$ & $-0.000(0.001)$ & $-0.000(0.001)$ & $-0.000(0.002)$ & $-0.005^{*}(0.003)$ & $\begin{array}{c}-0.009^{* *} \\
(0.005)\end{array}$ \\
\hline Log(GDP per capita) & $-0.001^{* *}(0.000)$ & $-0.001(0.001)$ & $-0.001(0.001)$ & $-0.108^{* * *}(0.007)$ & $-0.126^{* * *}(.010)$ & $\begin{aligned}-0.134^{* * *} \\
\\
(0.011)\end{aligned}$ \\
\hline gGDP & $0.002^{* * *}(0.000)$ & $0.002^{* * *}(0.000)$ & $0.002^{* * *}(0.000)$ & $-0.002(0.002)$ & $-0.002(0.002)$ & $\begin{array}{r}-0.004^{*} \\
(0.002)\end{array}$ \\
\hline Governance & $-0.001^{* * *}(0.000)$ & $-0.003^{* *}(0.001)$ & $-0.003^{* *}(0.001)$ & $-0.187^{* * *}(0.013)$ & $-0.200^{* * *}(0.013)$ & $\begin{array}{c}-0.210^{* * *} \\
(0.013)\end{array}$ \\
\hline Regulation & $-0.000^{* *}(0.000)$ & $-0.001^{* * *}(0.000)$ & $-0.001^{* * *}(0.000)$ & $-0.005^{* * *}(0.002)$ & $-0.006^{* * *}(0.001)$ & $\begin{array}{r}-0.002 \\
(0.001)\end{array}$ \\
\hline Constant & $0.002^{* * *}(0.000)$ & $0.004(0.004)$ & $0.007(0.005)$ & $18.541^{* * *}(1.152)$ & $18.241^{* * *}(1.124)$ & $\begin{array}{c}14.410^{* * *} \\
(1.189)\end{array}$ \\
\hline Year dummies & Yes & Yes & Yes & Yes & Yes & Yes \\
\hline No. of instruments & 28 & 28 & 28 & 29 & 29 & 29 \\
\hline $\operatorname{AR}(2)$ & 0.24 & 0.13 & 0.18 & 0.19 & 0.18 & 0.19 \\
\hline Hansen statistics & 0.22 & 0.12 & 0.11 & 0.11 & 0.12 & 0.11 \\
\hline Observations & 210 & 210 & 210 & 240 & 240 & 240 \\
\hline No. of banks & 30 & 30 & 30 & 30 & 30 & 30 \\
\hline
\end{tabular}

Standard errors in parentheses. ${ }^{* * *} p<0.01,{ }^{* *} p<0.05,{ }^{*} p<0.1$. Here, financial stability, competition, efficiency, bank size and liquidity are measured by standard deviation of ROA or NPL, Boone indicator using market share of loan, PCA of net interest margin ratio, operating efficiency ratio, working capital ratio and asset turnover ratio, log(Total asset) and loan-to-deposit ratio, respectively

per capita) are negative in all models. GDP growth rate is positively significant in model (1)-(3), when stability is measured by $\sigma \mathrm{ROA}$, and negative but not significant except model (6), when stability is measured by NPL. All these results are consistent with the result of baseline models confirming the robustness of our findings.

\section{Robustness check: alternative macroeconomic control variables}

Table 5 shows the results of robustness check of the baseline models using alternative macroeconomic control variables - log (GDP) and financial depth. We treat financial stability, competition, efficiency, bank size and liquidity as endogenous and log (GDP), financial depth and year dummies as exogenous. The results show lag of financial stability measured by $\log (Z$-score $)$ is positive and significant in all models, and the coefficients remain in between the coefficient of fixed effect $(0.46)$ and pooled (0.79) estimation ${ }^{1}$. The findings suggest that competition has a nonlinear relationship with stability and efficiency positively impacts stability. Bank size and liquidity are positively associated with financial stability. All results of our intended variables remain unchanged after considering alternate macroeconomic control variables. Log (GDP) is positively significant, and financial depth is negatively significant in all models. These results also confirm the findings of our baseline estimation. Overall, all results of the robustness checks are in 
Table 5 Robustness check using alternative control variables

\begin{tabular}{|c|c|c|c|}
\hline Variables & (1) & (2) & (3) \\
\hline Financial stability $_{t-1}$ & $\begin{array}{r}0.628^{* * *} \\
(0.045)\end{array}$ & $\begin{array}{r}0.635^{* * *} \\
(0.098)\end{array}$ & $\begin{array}{r}0.789 * * * \\
(0.116)\end{array}$ \\
\hline Competition $_{t-1}$ & $\begin{array}{l}7.798^{* *} \\
(3.937)\end{array}$ & $\begin{array}{c}15.900^{* * *} \\
(4.265)\end{array}$ & $\begin{array}{l}26.240^{* * *} \\
(5.778)\end{array}$ \\
\hline Competition ${ }_{t-1}^{2}$ & $\begin{array}{c}-7.690^{* *} \\
(3.736)\end{array}$ & $\begin{array}{l}-15.694^{* * *} \\
(4.148)\end{array}$ & $\begin{array}{l}-23.921^{* * *} \\
(5.190)\end{array}$ \\
\hline Efficiency $_{t-1}$ & & $\begin{array}{r}5.284^{* * *} \\
(1.343)\end{array}$ & $\begin{array}{l}2.773^{*} \\
(1.673)\end{array}$ \\
\hline Competition $_{t-1} \times$ Efficiency $_{t-1}$ & & & $\begin{array}{c}-2.378^{* * *} \\
(0.888)\end{array}$ \\
\hline Bank size $e_{t-1}$ & $\begin{array}{l}0.281 \\
(0.175)\end{array}$ & $\begin{array}{l}0.469^{* *} \\
(0.221)\end{array}$ & $\begin{array}{r}1.098^{* * *} \\
(0.331)\end{array}$ \\
\hline Liquidity $_{t-1}$ & $\begin{array}{l}0.005 \\
(0.057)\end{array}$ & $\begin{array}{c}-0.317^{* * *} \\
(0.057)\end{array}$ & $\begin{array}{l}-0.347^{* * *} \\
(0.055)\end{array}$ \\
\hline $\log (G D P)_{t-1}$ & $\begin{array}{r}1.671^{* * *} \\
(0.279)\end{array}$ & $\begin{array}{r}1.187^{* * *} \\
(0.322)\end{array}$ & $\begin{array}{r}1.702^{* * *} \\
(0.376)\end{array}$ \\
\hline Financial depth $h_{t-1}$ & $\begin{array}{l}-1.281^{* * *} \\
(0.258)\end{array}$ & $\begin{array}{c}-1.060^{* * *} \\
(0.260)\end{array}$ & $\begin{array}{l}-1.733^{* * *} \\
(0.364)\end{array}$ \\
\hline Governance $_{t-1}$ & $\begin{array}{r}-0.308 \\
(0.214)\end{array}$ & $0.243(0.316)$ & $\begin{array}{l}0.112 \\
(0.322)\end{array}$ \\
\hline Regulation $_{t-1}$ & $\begin{array}{r}0.425^{* * *} \\
(0.046)\end{array}$ & $\begin{array}{r}0.402^{* * *} \\
(0.051)\end{array}$ & $\begin{array}{r}0.405^{* * *} \\
(0.051)\end{array}$ \\
\hline Constant & $\begin{array}{l}0.200 \\
(0.138)\end{array}$ & $\begin{array}{r}4.102^{* * *} \\
(0.965)\end{array}$ & $\begin{array}{r}2.236^{*} \\
(1.217)\end{array}$ \\
\hline No. of instruments & 28 & 28 & 28 \\
\hline $\operatorname{AR}(2)$ & 0.37 & 0.51 & 0.36 \\
\hline Hansen statistics & 0.48 & 0.18 & 0.47 \\
\hline Observations & 210 & 210 & 210 \\
\hline No. of banks & 30 & 30 & 30 \\
\hline
\end{tabular}

Standard errors in parentheses. ${ }^{* * *} p<0.01,{ }^{* *} p<0.05,{ }^{*} p<0.1$. Here, financial stability, competition, efficiency, bank size, liquidity and financial depth are measured by log(Z-Score), Boone indicator using market share of loan, PCA of net interest margin ratio, operating efficiency ratio, working capital ratio and asset turnover ratio, log(Total asset), loan-to-deposit ratio and broad money-toGDP ratio, respectively

congruence with our main results, which establish the reliability of the research findings.

\section{Conclusion}

The deregulation of the financial industry has been intensifying the competition of the banking sector around the world and posing evolving challenges to the financial ecosystem. Against this backdrop, the impact of competition on financial stability has become a prime concern for different policy groups and academics, who have conducted numerous studies though ended up with contradictory findings. In addition to this, bank efficiency is another important factor, which is also very significant for ensuring financial stability. However, research initiative to explore the joint impact of competition and efficiency on financial stability is still in its infancy and tangled with mixed evidence. Therefore, to contribute in this field of research and fill the gap of exploring the competition-stability nexus at different levels of efficiency, we study the banking industry of Bangladesh based on a sample of 30 listed commercial bank over 2009-2017. To fulfill our research objectives, we use bank-level data and calculate the $Z$-score, Boone indicator for deposit and loan market and construct efficiency index, to measure stability, competition and efficiency, respectively of the selected banks. We consider different interaction terms to analyze the impact of competition on stability in the presence of efficiency. To address the possible endogeneity in our estimation, we apply the two-step system GMM.

Results of our study show that the relationship between competition and financial stability is curvature in nature, implying that competition contributes to stability only at a lower level; however, as competition intensifies, the favorable impact of competition tends to decline and turns unfavorable afterward. Our analysis thus confirms the perspective of both stability and fragility. Besides, the results also indicate that efficiency contributes to financial stability, though the positive impact of efficiency is moderated in the presence of competition. All our results are robust in respect of different robustness checks.

Our empirical findings have some policy implications. The results are significant to the debated relationship between competition and stability, which will assist to formulate appropriate policies for endorsing financial stability not only for Bangladesh but also for other emerging economies. Policy makers should consider both competition and efficiency to design optimal strategies for ensuring stability of banks as efficiency contributes to stability and competition might incentivize banks to enhance cost efficiency and reallocate profits from unsuccessful (inefficient) units to successful (efficient) ones; however, high competition is detrimental to the financial stability. Prudent policies should be taken to evaluate, approve and govern the restructuring and monitor the entrance of financial institution to prevent excessive competition in the industry. Moreover, policy makers should encourage financial innovation as well as use of fintech to improve the efficiency of the financial institutions' operation. 


\section{Abbreviations}

DEA: data envelopment analysis; E/TA: equity/total asset; GDP: gross domestic product; GMM: generalized method of moment; $\mathrm{HHI}$ : Herfindahl-Hirschman index; KMO: Kaiser-Meyer-Olkin; NPL: nonperforming loan; PCA: principal component analysis; ROA: return on asset; WDI: World Development Indicator.

\section{Acknowledgements}

The authors would like to express sincere gratitude to the editor and fou anonymous reviewers for their insightful comments and suggestions, which were useful in substantially improving the quality of the paper. Any remaining errors are ours.

\section{Authors' contributions}

Both authors contributed equally to this paper, and all authors have read and approved the manuscript.

\section{Funding}

Not applicable.

Availability of data and materials

The datasets used and/or analyzed during the current study are available from the corresponding author on reasonable request.
Ethics approval and consent to participate

Not applicable.

\section{Consent for publication}

Not applicable.

\section{Competing interests}

The authors declare that they have no competing interests.

\section{Author details}

${ }^{1}$ Zhongnan University of Economic and Law, Wuhan 430073, People's

Republic of China. ${ }^{2}$ Patuakhali Science and Technology University, Patuakhali, Bangladesh. ${ }^{3}$ University of Barishal, Barishal, Bangladesh.

\section{Appendix}

See Table 6.

Table 6 Description of variables used

\begin{tabular}{|c|c|c|}
\hline Variables & Description/measurement & Source \\
\hline \multicolumn{3}{|l|}{ Dependent variable } \\
\hline \multirow[t]{3}{*}{ Financial stability } & $\log (Z$-score $)=\log \left(\frac{\left(\text { ROA }+\frac{\text { Equity }}{\text { Assets }}\right)}{\sigma \text { ROA }}\right)$ & Author's calculation \\
\hline & Volatility of $\mathrm{ROA}=\sigma \mathrm{ROA}$ & Author's calculation \\
\hline & Nonperforming loan ratio (NPL) & Financial statement \\
\hline \multicolumn{3}{|l|}{ Independent variables } \\
\hline Competition & Boone indicator $=\ln (\text { Market share })_{\text {it }}=\alpha+\beta \ln (\text { Marginal cost })_{\text {it }}$ & Author's calculation \\
\hline \multirow[t]{2}{*}{ Efficiency } & $\begin{array}{l}\text { Efficiency index }=\text { PCA of net interest margin, working capital ratio, asset turnover } \\
\text { ratio and operating efficiency ratio }\end{array}$ & Author's calculation \\
\hline & Operating efficiency ratio & Author's calculation \\
\hline \multicolumn{3}{|l|}{ Control variables } \\
\hline Bank size & $\log ($ total asset) & Financial statement \\
\hline Liquidity & Loan-to-deposit ratio & Author's calculation \\
\hline Economic growth & Growth of GDP & WDI, WB \\
\hline \multirow[t]{2}{*}{ Economic condition } & $\log (G D P)$ & WDI, WB \\
\hline & $\log (G D P$ per capita) & WDI, WB \\
\hline Financial depth & Broad money to GDP & WDI, WB \\
\hline Governance & Composite governance index $=$ PCA of six governance indicators & WGI,WB \\
\hline Regulation & Regulation indicator of economic freedom index & Fraser institute \\
\hline
\end{tabular}


Received: 17 April 2020 Accepted: 30 November 2020

Published: 21 January 2021

\section{References}

1. Ahamed MM, Mallick SK (2019) Is financial inclusion good for bank stability? International evidence. J Econ Behav Organ 157:403-427. https://doi. org/10.1016/j.jebo.2017.07.027

2. Alber N (2017) Banking efficiency and financial stability: which causes which? A panel analysis. In: Tsounis N, Vlachvei A (eds) Advances in applied economic research. Springer proceedings in business and economics. Springer, Cham. https://doi.org/10.1007/978-3-319-48454-9_7

3. Allen F, Gale D (2000) Financial contagion. J Polit Econ 108(1):1-33. https ://doi.org/10.1086/262109

4. Allen F, Gale D (2004) Competition and financial stability. J Money Credit Bank 36(3):453-480. https://doi.org/10.1353/mcb.2004.0038

5. Altunbas Y, Carbo S, Gardener EPM, Molyneux P (2007) Examining the relationships between capital, risk and efficiency in European banking. Eur Financ Manag 13(1):49-70. https://doi.org/10.1111/j.1468036X.2006.00285.X

6. Amidu M, Wolfe S (2013) Does bank competition and diversification lead to greater stability? Evidence from emerging markets. Rev Dev Finance 3(3):152-166. https://doi.org/10.1016/j.rdf.2013.08.002

7. Anginer D, Demirguc-Kunt A, Zhu M (2014) How does competition affect bank systemic risk? J Financ Intermed 23(1):1-26. https://doi. org/10.1016/j.jfi.2013.11.001

8. Bangladesh Bank (2019) Annual report, 2017-2018. Bangladesh Bank. Retrieved from https://www.bb.org.bd/pub/annual/anreport/ar1718/ full_2017_2018.pdf. Accessed 10 Apr 2020

9. bdnews24.com (2019) Bangladesh Bank approves three more private commercial banks. bdnews24.com. Retrieved from https://bdnews24. com/economy/2019/02/17/bangladesh-bank-approves-three-moreprivate-commercial-banks. Accessed 10 Apr 2020

10. Beck T, Jonghe OD, Schepens G (2013) Bank competition and stability: cross-country heterogeneity. J Financ Intermed 22(2):218-244. https:// doi.org/10.1016/j.jfi.2012.07.001

11. Berger AN, DeYoung R (1997) Problem loans and cost efficiency in commercial banks. J Bank Finance 21(6):849-870. https://doi. org/10.1016/S0378-4266(97)00003-4

12. Berger AN, Hannan TH (1998) The efficiency cost of market power in the banking industry: a test of the "quiet life" and related hypotheses. Rev Econ Stat 80(3):454-465

13. Berger AN, Klapper LF, Turk-Ariss R (2009) Bank competition and financial stability. J Financ Serv Res 35(2):99-118. https://doi.org/10.1007/ s10693-008-0050-7

14. Blundell R, Bond S (1998) Initial conditions and moment restrictions in dynamic panel data models. J Econom 87(1):115-143. https://doi. org/10.1016/S0304-4076(98)00009-8

15. Bond SR (2002) Dynamic panel data models: a guide to micro data methods and practice. Port Econ J 1:141-162. https://doi.org/10.1007/ s10258-002-0009-9

16. Boone J (2001) Intensity of competition and the incentive to innovate. Int J Ind Organ 19(5):705-726. https://doi.org/10.1016/S0167 -7187(00)00090-4

17. Boone J (2008) A new way to measure competition. Econ J 118(531):1245-1261. https://doi.org/10.1111/j.1468-0297.2008.02168.x

18. Boyd JH, Nicolo GD (2005) The theory of bank risk taking and competition revisited. J Finance 60(3):1329-1343. https://doi.org/10.111 1/j.1540-6261.2005.00763.x

19. Carletti E, Hartmann P (2002) Competition and stability: what's special about banking? (ECB working paper 146). European Central Bank: Frankfurt. Retrieved from https://www.ecb.europa.eu/pub/pdf/scpwp s/ecbwp146.pdf. Accessed 25 Mar 2020

20. Claessens S, Laeven $L$ (2004) What drives bank competition? Some international evidence. J Money Credit Bank 36(3):563-583

21. Corbae D, Ross L (2019) Competition, stability, and efficiency in the banking industry. Manuscript, University of Wisconsin. https://www. cemfi.es/ftp/pdf/papers/wshop/CL052319.pdf. Accessed 25 Mar 2020

22. Danisman GO, Demirel P (2019) Bank risk-taking in developed countries: the influence of market power and bank regulations. J Int
Financ Mark Inst Money 59(C):202-217. https://doi.org/10.1016/j.intfi n.2018.12.007

23. Danisman GO, Demirel P (2019) Bank risk-taking in developed countries: the influence of market power and bank regulations. J Int Financ Mark Inst Money 59:202-217. https://doi.org/10.1016/j.intfi n.2018.12.007

24. Dutta KD, Saha M (2020) Nexus of governance, macroprudential policy and financial risk: cross-country evidence. Econ Change Restruct. https //doi.org/10.1007/s10644-020-09301-9

25. Fiordelisi F, Marques-lbanez D, Molyneux P (2010) Efficiency and risk in European Banking (working paper series no 1211/June 2010). Retrieved from https://www.ecb.europa.eu/pub/pdf/scpwps/ecbwp 1211.pdf. Accessed 25 Mar 2020

26. Fraser Institute (2019) Economic freedom. https://www.fraserinst itute.org/economic-freedom/dataset?geozone $=$ world\&page $=$ datas et $\&$ min-year $=2 \&$ max-year $=0 \&$ filter $=0$. Accessed 21 Sept 2020

27. Fu XM, Lin YR, Molyneux P (2014) Bank competition and financial stability in Asia Pacific. J Bank Finance 38(1):64-77. https://doi.org/10.1016/j. jbankfin.2013.09.012

28. Hotelling H (1933) Analysis of a complex of statistical variables into principal components. J Educ Psychol 24(6):417-441. https://doi. org/10.1037/h0071325

29. Islam S (2018) BB set to place three new bank bids before its board. The Financial Express. Retrieved from https://thefinancialexpress.com bd/economy/bb-set-to-place-three-new-bank-bids-before-its-board -1540784975. Accessed 10 Apr 2020

30. Jeon JQ, Lim KK (2013) Bank competition and financial stability: a comparison of commercial banks and mutual savings banks in Korea. Pac Basin Finance J 25:253-272. https://doi.org/10.1016/j.pacfi n.2013.10.003

31. Kasman A, Carvallo O (2014) Financial stability, competition and efficiency in Latin American and Caribbean Banking. J Appl Econ 17(2):301-324. https://doi.org/10.1016/S1514-0326(14)60014-3

32. Kasman S, Kasman A (2015) Bank competition, concentration and financial stability in the Turkish banking industry. Econ Syst 39(3):502517. https://doi.org/10.1016/j.ecosys.2014.12.003

33. Keeley MC (1990) Deposit insurance, risk, and market power in banking. Am Econ Rev 80(5):1183-1200

34. Koetter M, Kolari JW, Spierdijk L (2012) Enjoying the quiet life under deregulation? Evidence from adjusted Lerner indices for U.S. Banks. Rev Econ Stat 94(2):462-480

35. Llewellyn DT (2007) The northern rock crisis: a multi-dimensional problem waiting to happen. J Financ Regul Compliance 16(1):35-58. https //doi.org/10.1108/13581980810853208

36. Martinez-Miera D, Repullo R (2010) Does competition reduce the risk of bank failure? Rev Financ Stud 23(10):3638-3664

37. Morgan PJ, Pontines V (2014) Financial stability and financial inclusion (Asian Development Bank Institute working paper series no. 488). Asian Development Bank. Retrieved from https://www.adb.org/sites/default/ files/publication/154225/adbi-wp488.pdf. Accessed 25 Mar 2020

38. Noman AHM, Gee CS, Isa CR (2018) Does bank regulation matter on the relationship between competition and financial stability? Evidence from Southeast Asian countries. Pac Basin Finance J 48(C):144-161. https://doi.org/10.1016/j.pacfin.2018.02.001

39. Owen AL, Pereira JM (2018) Bank concentration, competition, and financial inclusion. Rev Dev Finance 8(1):1-17. https://doi. org/10.1016/j.rdf.2018.05.001

40. Phan HT, Anwar S, Alexander WRJ, Phan HTM (2019) Competition, efficiency and stability: an empirical study of East Asian commercial banks. N Am J Econ Finance. https://doi.org/10.1016/j.najef.2019.10099 0

41. Pruteanu-Podpiera A, Weill L, Schobert F (2008) Banking competition and efficiency: a micro-data analysis on the Czech banking industry. Comp Econ Stud 50:253-273. https://doi.org/10.1057/palgrave. ces. 8100248

42. Pruteanu-Podpiera A, Weill L, Schobert F (2016) Banking competition and efficiency: a micro-data analysis on the Czech Banking Industry. In: Brada JC, Wachtel P (eds) Global banking crises and emerging markets. Palgrave Macmillan, London. https://doi.org/10.1007/978-1-137-56905 $-94$ 
43. Roodman D (2009) A note on the theme of too many instruments. Oxford Bull Econ Stat 71(1):135-158. https://doi.org/10.111 1/j.1468-0084.2008.00542.x

44. Saha M, Dutta KD (2020) Nexus of financial inclusion, competition, concentration and financial stability: cross-country empirical evidence. Compet Rev. https://doi.org/10.1108/CR-12-2019-0136

45. Saif-Alyousfi AYH, Saha A, Md-Rus R (2020) The impact of bank competition and concentration on bank risk-taking behavior and stability: evidence from GCC countries. N Am J Econ Finance 51, 100867. https ://doi.org/10.1016/j.najef.2018.10.015

46. Schaeck K, Cihák M (2014) Competition, efficiency, and stability in banking. Financ Manag 43(1):215-241. https://doi.org/10.1111/ fima.12010

47. Schaeck K, Cihák M (2008) How does competition affect efficiency and soundness in banking? New empirical evidence (working paper series no. 932). European Central Bank. Retrieved from https://www.ecb. europa.eu/pub/pdf/scpwps/ecbwp932.pdf?8eaa301028741bf824b1 2e8ab5a4a707. Accessed 25 Mar 2020

48. Schaeck K, Cihak M, Wolfe S (2009) Are competitive banking system more stable? J Money Credit Bank 41(4):711-734. https://doi.org/10.11 11/j.1538-4616.2009.00228.x

49. Tan Y, Floros C (2013) Risk, capital and efficiency in Chinese banking. J Int Financ Mark Inst Money 26:378-393. https://doi.org/10.1016/j.intfi n.2013.07.009
50. Uddin Z AKM (2020) Four new banks to get licence: BB bows to pressure from govt high-ups, starts process. The Daily Star. Retrieved from https://www.thedailystar.net/backpage/news/four-new-banks-getlicence-1653208. Accessed 10 Apr 2020

51. Vives $X$ (2008) Innovation and competitive pressure. J Ind Econ 56(3):419-469. https://doi.org/10.1111/j.1467-6451.2008.00356.x

52. Weygandt JJ, Kimmel PD, Kieso DE (2016) Accounting principles, 12th edn. Wiley, New Delhi

53. World Bank (2019a) The Worldwide Governance Indicator Dataset [Data file]. Retrieved from https://info.worldbank.org/governance/wgi/. Accessed 1 Apr 2020

54. World Bank (2019b) The World Development Indicators (WDI) [Data file]. Retrieved from https://databank.worldbank.org/source/world-devel opment-indicators. Accessed 1 Apr 2020

\section{Publisher's Note}

Springer Nature remains neutral with regard to jurisdictional claims in published maps and institutional affiliations.

\section{Submit your manuscript to a SpringerOpen ${ }^{\circ}$ journal and benefit from:}

- Convenient online submission

- Rigorous peer review

- Open access: articles freely available online

- High visibility within the field

- Retaining the copyright to your article

Submit your next manuscript at $\gg$ springeropen.com 